20. Чанги Дарвиш Али. Трактат о музыке : [рукопись] / пер. с перс-тадж. Д. Рашидовой. - Ташкент : Б-ка НИИ искусствознания, 1982. - 81 с.

21. Иброхимов, О. Мақом ва макон. - Тошкент : Мовароуннахр, 1996. - 96 с.

22. Ражабов, И. Мақомлар. - Тошкент : Санъат, 2006. - 404 с.

23. Ибрагимов, О. Фергано-Ташкентские макомы. - Ташкент : Media Land, 2006. - 175 с.

24. Ражабов, И. Мақомлар масаласига доир. - Тошкент : Ўзадабийнашр, 1963. - 300 с.

25. Рашидова, Д. Нажмиддин Кавкабий Бухорий // История и современность: проблемы музыкальной культуры Узбекистана, Туркменистана и Таджикистана : [сб. ст.]. - Москва : Музыка, 1972. - С. 49-53.

26. Урмавий, С. Китобул-адвор. - Тошкент : СИТИ кутубхонаси. -58 с.

27. Семёнов, А. А. Среднеазиатский трактат по музыке Дервиша Али (XVII в.). - Ташент : Тип. № 1 , 1938. $-124 \mathrm{c}$.

28. Рахмонов, М. Ўзбек театри тарихи (XVIII асрдан XX аср аввалигача ўзбек театр маданиятининг тараққиёт йўллари). - Тошкент : Фан, 1968. - 480 с.

29. Нисорий, Х. Музаккири ахбоб (Дўстлар ёдномаси): Тазкира. - Тошкент : Қодирий номидаги халқ мероси нашриёти, 1993. - 343 с.

30. Айни, С. Асарлар : [6 т.]. - Тошкент : Бадиий адабиёт, 1957. - 520 с.

31. Фитрат, А. Ўзбек калссик мусиқаси ва унинг тарихи. - Тошкент : Фан, 1993. - 56 с.

Ghani M. Khoudoev, Ph. D. in Art Criticism,

State Institute of Art and Culture of Uzbekistan (Tashkent, Uzbekistan) gani_khudoyev@mail.ru

\title{
EVOLUTION OF MUSICAL CULTURE OF BUKHARA, UZBEKISTAN
}

Abstract. Bukhara (now is administrative capital of Bukhara Oblast, Uzbekistan) for many centuries kept glory of cultural center of Central Asia. Bukhara's artists, architectures, masters of arts and crafts, musicians made a substantial contribution to treasury of the world's artistic culture. A notable role Bukhara has played in development of tradition musical culture of peoples of the East, this pointed out by, in particular, a geographic range of distribution of numerous handwritten works by local authors dedicated to various issues of musical theory and practice, as well as a phenomenon of perception of Bukhara's local musical traditions by ethnical communities from Middle and Near East that has become a subject matter for a wide circle of historians, theorists of literature, specialists in art criticism, music studies.

Key words: culture, a scholar, a worker of art, a bastakor (a musician, singer and melodist), муганни (певеи, поющий под собственный аккомпанемент), саз (музыкальный инструмент), маком.

УДК 39:[338.486:711.2(470+571)]

DOI 10.32340/2414-9101-2020-2-57-62

О. Ю. Нельзина,

Российский научно-исследовательский институт культурного и природного наследия им. Д. С. Лихачёва (Москва, Россия) olgasviridoff@yandex.ru

\section{ИСТОРИКО-КУЛЬТУРНЫЙ ПОТЕНЦИАЛ ТЕРРИТОРИЙ И ЕГО ИСПОЛЬЗОВАНИЕ ПРИ ОРГАНИЗАЦИИ КОМПЛЕКСОВ ЭТНОГРАФИЧЕСКОЙ НАПРАВЛЕННОСТИ}

Аннотация. Рассмотрен потенциал интеграции этнографических комплексов (туристскоэтнографических центров, этнографических парков, этнодеревень, этностойбищ, этноаулов и пр.), включающих памятники национальной истории и культуры, в систему мероприятий, реализуемых органами государственной и муниципальной власти в области организации социокультурной среды, обеспечивающей актуализацию историко-культурного наследия этнических сообществ 
посредством развития этнокультурного, познавательного, образовательного видов туризма. Развитие соответствующей инфраструктуры вокруг объектов, составляющих ядро этнокультурного ландшафта территории, вносит весомый вклад в укрепление туристской и инвестиционной привлекательности региона, выступает одним из условий повышения уровня качества жизни населения территории, позволяет задействовать ценный потенциал воспитания этнокультурной идентичности личности и социальных групп в полиэтничных регионах современной России.

Ключевые слова: этнографический комплекс, историко-культурный потенциал региона, культурная среда, материальное наследие, историческая память, исторический ландмафт, туризм, образовательные программы.

Появление этнографических комплексов обусловлено необходимостью сохранения, консервации и изучения памятников народной архитектуры и быта. Эти объекты отражают особенности культурных традиций, выступая оплотом местной идентичности, тем самым они способствуют сохранению исторической памяти территорий. Комплекс мероприятий по охране объектов истории и культуры, организуемых при этом, позволяют спасти и восстановить множество объектов народного зодчества. Стал возможен открытый (или частично открытый) доступ публики к ним, вместе с этим повысился интерес к истории их создания [1, с. 142].

Внимание к подобным объектам возрастает также вследствие агрессивного влияния городской среды, а также утраты национальных и культурных традиций и обычаев. Историкоэтнографические парки (музеи, деревни) популяризуют культуру местного этноса. Они являются объектами, сохранившими свой «этнический тип» и обладающими признаками, характерными для данной традиционной культуры. Этничность представляется свойствами этнической общности, обозначая ее отличия от других образований. Она выступает и как живая культурная традиция в разных ее проявлениях - от фольклора до национальной кухни, так и как музейный экспонат. Так как этничность сама по себе является формой общественной организации культурных сообществ, значение имеет наличие общей исторической памяти. Общие элементы культуры, представление об общем происхождении приводит к появлению чувства групповой солидарности [1, c. 145].

Этнографические комплексы, туристско-этнографические центры, этнографические парки, этнографические деревни, этностойбища, этноаулы-все эти объекты популяризуют местную культуру. В целом, появление этнокультурных образований в многонациональных регионах является общемировой тенденцией, посетителей привлекает возможность посетить среду, не подверженную влиянию антропогенных факторов. Важную роль играют обширность территорий, степень их освоенности, емкость, то есть способность вместить определенное количество приезжих, природные особенности, ландшафтное разнообразие, экологическая обстановка.

Национальные этнографические комплексы нередко создаются по инициативе местных властей и рассматриваются ими как элементы национальной политики в многонациональных регионах. При строительстве комплексов происходит процесс моделирования материальных и духовных составляющих, соединение различных компонентов. Таким образом, происходит процесс поддержки этнокультурной идентичности в регионах. Постройки нередко представляют собой образные стилизации этноархитектурных стилей и аутентичность не имеет большого значения.

При организации комплексов этнографической направленности, как правило, ориентируются на историко-культурный потенциал территорий, определяющий также социокультурную среду данной местности. Во многих российских регионах множество богатых историей мест, которые возможно представить в тематике создаваемых исторических комплексов. В России сформировано разнообразное культурное поле для выбора тем, которые возможно использовать в качестве главной сюжетной линии.

Культурное наследие представлено уникальными традициями, обычаями, особенностями хозяйственной деятельности и формирует у туристов облик посещаемых территорий. В качестве культурного наследия регионов выступают также произведения искусства, созданные местными авторами, народные промыслы, легенды и т. д. Следовательно, культурный потенциал страны, города или района способен обеспечить уникальную тематическую специфику. Оно включает в себя все памятники, расположенные на местах: культовая и гражданская архитектура, историче- 
ские города, типичные сельские поселения, памятники ландшафтной архитектуры, памятники археологии, объекты этнографии, народные промыслы и ремесла, центры декоративно-прикладного искусства.

Ресурсная база потенциала рассматриваемых территорий определяется, как правило, совокупностью природных, антропогенных, климатических, социокультурных факторов. Важнейшую роль в формировании целостного восприятия также выполняет исторический ландшафт. Согласно одной из точек зрения, этнографические комплексы выступают как новый тип культурного ландшафта, «имитационный культурный ландшафт» [2, с. 11]. Анализируя деятельность этнографических комплексов в России, можно сделать вывод, что они успешно «работают» на имидж регионов, при их организации повышается эстетическая привлекательность территорий.

Оценка историко-культурного и природного потенциала региона включает в себя интегральную оценку материального, нематериального культурного и природного наследия, их потенциал и эстетическую привлекательность. Результаты таких выводов позволяют акцентировать внимание на аспектах развития территорий, прогнозируемой коммерческой успешности проекта, составить в целом представление о формируемом образе местности [3, с. 55].

В современных условиях этнографические комплексы вынуждены бизнес-ориентироваться с целью извлечения средств на развитие. Это и проведение тематических мастер-классов, и организация праздников и многое другое.

Историко-культурный потенциал территории играет важную роль также при разработке региональных стратегий развития туристической отрасли и неразрывно связан с образом региона, со своеобразным «брендом» [4]. Однако существуют примеры расположения объектов, популяризирующих культуру и наследие отдельных этносов в других локациях. Это, например, этнокультурный комплекс «Хаски Лэнд» в Подмосковье. Его функционал поддерживается за счет интереса к «далекой, малоизвестной» в Центральном федеральном округе этнической общности. Брендирование в целом является отображением собственной идентичности, «свои» символы, ценности - все это создает привлекательность для туристов и поднимает чувство самосознания местного населения. Одновременно с этим происходит процесс повышения конкурентоспособности региона за счет привлечения туристов, мигрантов, инвесторов. С появлением такого рода объектов происходит повышение качества жизни местного населения, увеличение количества объектов социально-бытового обслуживания.

Функциями этнографических комплексов, помимо охраны объектов этнографического наследия, также являются просветительские, образовательные и туристические. Часто историкоэтнографические парки, имеющие историческую, архитектурную и иную ценность и тесно связанные с индустрией туризма, выполняют роль информационных центров и представляют регионы. Но вместе с тем, при продвижении частных инициатив требуется государственная поддержка, необходимо «расширять» информационное поле в целях более успешного развития новых образований.

Проводя анализ уровня подготовленности регионов к увеличению туристического потока, необходимо опираться на данные о природно-экономическом потенциале территории, темпах экономического роста, занимаемого места в экономике страны, эффективности производства, уровня жизни населения [5, с. 50]. Также необходимо учитывать степень освоенности территории, плотность насыщения ее инфраструктурными компонентами, уровень обеспечения телекоммуникационными средствами связи и т. д.

С точки зрения массового туриста образ территории формируется благодаря ее особенностям, важную роль играет психологическая составляющая целевой аудитории, отмечено, что образы, сформированные ранее, трансформируются в процессе исследования. Система этнических деревень и музеев национального быта в России неразрывно связана с этнокультурным туризмом, и в определенной степени является его инфраструктурой. Целью этого вида туризма является приобщение широких масс к этнокультурному наследию. Региональный туризм является социально ориентированным явлением, напрямую влияет на общественное устройство, выполняет ряд социальных функций. Среди них такие как: повышение уровня образования и культуры, организация отдыха путем использования социальных и культурных ресурсов, адаптация и интеграция членов общества в новую социальную среду, получение новых впечатлений, снижение уровня психофизиологических нагрузок. 
Познавательный туризм является частью социальной и экономической сфер деятельности, организация экскурсионно-туристских маршрутов позволяет в полной мере использовать потенциал территорий. Вместе с тем данная инфраструктура позволяет одновременно обслуживать туристов и местное население, что способствует туристскому освоению мест, улучшает условия жизни жителей данного района. Как правило, наблюдается рост показателей - появление большего количества мест размещения и питания, создания новых рабочих мест, увеличение объемов торговли, улучшение качества телекоммуникационных связей, транспортного обеспечения и т. д. Важным фактором при проектировании объектов, связанных с туристической отраслью, а в нашем случае это тематические этнографические комплексы является кадровое обеспечение. Необходимо привлечение профильных специалистов, также штат комплексов должен быть укомплектован работниками технических и обслуживающих структур.

В отношении современного развития туризма в среде специалистов существует мнение, что традиционная организация этого процесса, проходящего в рамках существующих административно-территориальных образований определенным образом его замедляет. Выдвигаются современные предложения по районированию территорий, созданию сети рекреационных центров в приоритетных (ключевых) местах. То есть формирование «единого туристско-рекреационного пространства», основанного на создании общерегиональных, межрегиональных «туристских коридоров», по которым распределяются основные туристские потоки.

В современных российских условиях многонациональной культурной специфики регионы России обладают высоким потенциалом для успешной работы этнографических комплексов. Отмечается рост количества историко-этнографических парков, этнографических музеев под открытым небом и этнодеревень, большое их количество расположено в многонациональных регионах. На сегодняшний момент, например, этнические деревни функционируют и строятся практически во всех федеральных округах, однако количество их разнится и зависит от множества факторов [6].

При создании таких объектов происходит процесс моделирования духовной культуры - на их базе проводятся фольклорные фестивали, праздничные обрядовые действия, справляются свадьбы по этническим образцам. Во время пребывания в таких поселениях посетители имеют возможность принять участие в традиционных занятиях населения - собирательстве, охоте и рыбной ловле, ремеслах, попрактиковаться в верховой езде.

Безусловно, создание таких объектов претворяет собой комплекс определенных мер: проведение инженерных исследований для определения состояния объектов, изучение особенностей геологической среды региона, археологические работы, в ходе которых, как правило, обнаруживаются новые объекты культурного наследия.

Важным фактором в вопросах успешной работы этнографических комплексов является оценка посещаемости и уровня антропогенной нагрузки. Как правило, в силе остается «коллизия сезонности», антропогенная нагрузка в большинстве случаев распределяется крайне неравномерно. В первую очередь, это обусловлено ограниченным временем посещения (обычно, в течение светового дня), отсутствием возможности размещения туристов в гостиницах и крайне слабо развитой туристической инфраструктурой. Это касается объектов, находящихся на отдаленном расстоянии от крупных городов. Важна финансовая составляющая, в процессе эксплуатации зданий и сооружений возникает необходимость реставрации, проведение укрепительных и очистных работ, для этого также необходимы финансовые вливания.

Этнографические парки, развивающиеся на базе музеев, обладают самой большой научной ценностью. Благодаря наличию в нашей стране большого количества музеев под открытым небом это направление можно считать очень перспективным. В отношении современных музейных экспозиций наиболее успешным является комплексный подход, где задействованы все средства художественной выразительности и организующие ее компоненты. Ведь основой научного и художественного решения экспозиции является экспонат-подлинник [7, с. 28]. Перспективным направлением является организация «рекреационных» пространств в непосредственной близости от музейно-мемориальной территории. Известным примером этому является московский музей-заповедник «Коломенское», создавший дополнительные историкоэтнографические пространства с домами-новоделами и реконструированным «Дворцом Алексея 
Михайловича» [1, с. 151].

В качестве успешных примеров можно привести также Костромской музей народной архитектуры и быта, возникший в 1955 году. Сейчас там расположено порядка тридцати построекэкспонатов - крестьянские избы, церковные постройки, амбары, бани. Также это Пермский этнографический парк истории реки Чусовой, основанный в 1981 году. На территории парка сохранены уникальные постройки XIX века, перевезенные из разных мест - крестьянские избы, церковь, трапезная, кузница, сельская лавка. В этих музеях представлены информационные и игровые программы, проводятся экскурсии и мастер - классы, организуются различные праздники в народных традициях.

В начале 2000-х годов в российских музеях формируются новые направления развития, в том числе увеличивается рост количества этнодеревень как самостоятельных объектов. Появляются новые типы этнокультурных образований, новые подтипы «этнодеревенских культурных ландшафтов»- национальные деревни, региональные этнодеревни национальных республик, локальные этнодеревни, включая этнодеревни малых народов России, этностойбища, этноаулы. Развитие подобных объектов связано как с увеличением объемов внутреннего туризма, также и с глобальными процессами, происходящими в национальной политике, с процессами утверждения региональной и местной идентичности.

Главной задачей при создании этнографических объектов является сохранение и популяризация культурного наследия России, необходимо акцентирование на традиционной региональной культуре. В целях повышения уровня знания отечественной истории успешными становятся мероприятия, представляющие события в игровой форме, с целью вовлечения посетителей в представление. Театрализованные мероприятия и реконструкции с помощью сотрудников, либо приглашенных аниматоров, одетых соответственно народным традициям и эпохе, создают наглядное представление об этносе, позволяют «погрузиться» на время в предлагаемые обстоятельства.

Создание комплексов этнографической направленности на территориях, обладающих культурной памятью представляет наглядные примеры реализации принципов мира и согласия, расовой, межнациональной и религиозной терпимости. В современных условиях они способствуют воспитанию уважения к традициям различных народов, поиску взаимопонимания в постоянно ведущемся межэтническом диалоге культур.

\section{Список литературы}

1. Нельзина, О. Ю. Тематические парки как учреждения музейного типа: проблемы и перспективы / О. Ю. Нельзина, А. В. Окороков, Т. П. Поляков. - Москва : Ин-т наследия, 2019. - 288 с.

2. Калуцков, В. Н. Этническая деревня - новый тип культурного ландшафта // Теория и практика планирования культурного ландшафта: матер. Всерос. науч.-практ. конф. (г. Саранск, нояб. 2010 г.).Саранск : Изд-во Мордовского ун-та, 2010. - С. 7-15.

3. Климанова, О.А. Природный и историко-культурный потенциал региона как основа формирования туристского образа территории // Современные проблемы сервиса и туризма. - 2008. - № 4. C. $49-55$.

4. Динни, К. Брендинг территорий. Лучшие мировые практики / под ред. К. Динни ; пер. с англ. В. Сечной. - Москва : Манн, Иванов и Фербер, 2013. - 336 c. - URL: http://www.universalinternetlibrary.ru/ book/53403/chitat_knigu.shtml (дата обращения: 11.05.2020).

5. Жукова, В. В. Уровень освоенности территории как база устойчивого развития экономики региона // Региональная экономика: теория и практика. -2012 . - № 42. - С. 50-55.

6. Свиридова, О. Ю. Расположение и некоторые особенности существующих и проектируемых этнографических музеев, парков этнографической реконструкции и этнических деревень на территории Российской Федерации // Журнал Института наследия. - 2016. - № 4. - URL: http://naslediejournal.ru/ru/journals/13/108.html (дата обращения: 28.05.2020 г.).

7. Майстровская, М. Т. Архитектурно-художественные компоненты в музейной экспозиции // Музееведение. Искусство музейной экспозиции и техническое оснащение музеев : [сб. науч. тр.] / [науч. ред. А. Д. Тимрот]. - Москва : НИИК, 1985. - С. 28-29. 
Olga Yu. Nel'zina,

Dmitri Likhachyov Russian Cultural and Natural Heritage Research Institute (Moscow, Russia) olgasviridoff@yandex.ru

\title{
REGIONAL HISTORICAL AND CULTURAL POTENTIAL, ITS APPLIANCE IN ESTABLISHING ETHNOGRAPHIC COMPLEXES
}

\begin{abstract}
The article considers a potential of integration of ethnographic complexes (such as touristic and ethnographic centers, ethnographic parks, ethnic villages, ethnic settlements, ethnic mountain village, etc.) that include monuments of ethnic history and culture into a system of measures managed by state and municipal authorities in organizing social and cultural environment that helps to popularize historical and cultural heritage of ethnic communities through development of ethnocultural, educative tourism. The development of sufficient infrastructure around the places that run a core of ethnocultural landscape of an area contributes to strengthening of touristic and investment attractiveness of a region, can be considered as a condition for growth of a level of local population's life quality, lets to involve valuable potential of a person and a social group's ethnic identity education in multi-cultured regions of modern Russia.
\end{abstract}

Key words: complex of ethnographic sites, historical and cultural potential of a region, cultural environment, tangible heritage, historical memory, historical landscape, tourism, education programs. 